\title{
Lepidopterans and their parasitoids on okra plants in Riberão Preto (SP, Brazil)
}

\author{
Lepidópteros e seus parasitoides em cultura de quiabo em Ribeirão Preto, SP, Brasil
}

\author{
Rogéria Inês Rosa Lara' ${ }^{\mathrm{I}}$ Bruno Rafael Spera' ${ }^{\mathrm{I}}$ Danielle Roberta Versuti ${ }^{\mathrm{I}}$ \\ Daniell Rodrigo Rodrigues Fernandes ${ }^{\mathrm{I}, \mathrm{II}}$ Terezinha Monteiro Santos-Cividanes ${ }^{\mathrm{I}}$ \\ Nelson Wanderley Perioto, II
}

\begin{abstract}
The aim of this study was to identify the defoliating ABSTRACT lepidopterans and their parasitoids occurring on okra plants in the district of Riberão Preto city (SP. Brazil). Caterpillars were collected by hand from an experimental field of okra, in March and April, 2009. They were placed individually on Petri dishes lined with wet filter paper, containing shredded okra leaves, and kept in a climactic chamber $\left(25 \pm 1^{\circ} \mathrm{C}, 12: 12 \mathrm{~h}\right.$ light/ dark photoperiod, $R H \quad 70 \pm 10 \%)$ until the emergence of lepidopterans and/or parasitoids. In all, 63 lepidopterans were obtained: three species of Noctuidae, Anomis flava (Fabricius), Spodoptera frugiperda (Smith) and Pseudoplusia includens (Walker); one of Pieridae, Ascia monuste orseis (Godart), and an unidentified species of Tortricidae. One unidentified tachinid fly (Diptera) and the Hymenoptera parasitoids Copidosoma floridanum (Ashmead) (Encyrtidae) and Euplectrus $s p$. (Eulophidae) emerged from A. flava, while C. floridanum and an unidentified tachinid, from $\boldsymbol{P}$. includens. This is the first report of an association between the herbivores $\boldsymbol{S}$. frugiperda, $\boldsymbol{P}$. includens and $\boldsymbol{A}$. monuste orceis, the parasitoids $\boldsymbol{C}$. floridanum and Euplectrus sp. on okra plants.
\end{abstract}

Key words: Abelmoschus esculentus, Copidosoma floridanum, Euplectrus, parasitic Hymenoptera, Tachinidae.

\section{RESUMO}

Este estudo objetivou identificar lepidópteros desfolhadores e seus parasitoides em cultura de quiabo em Ribeirão Preto, SP, Brasil. As lagartas foram coletadas através de catação manual entre março e abril de 2009, individualizadas em placas de Petri forradas com papel filtro umedecido contendo pedaços de folhas de quiabo e mantidas sob condições controladas $\left(25 \pm 1^{\circ} \mathrm{C}, 12\right.$ horas de fotofase, $70 \pm 10 \%$ de UR) até a obtenção dos adultos de lepidópteros el ou de seus parasitoides. Foram obtidos 63 adultos de lepidópteros: três espécies de Noctuidae, Anomis flava (Fabricius), Spodoptera frugiperda (Smith), Pseudoplusia includens (Walker), uma de Pieridae, Ascia monuste orseis (Godart) e uma de Tortricidae não identificada. Uma espécie não identificada de taquinídeo (Diptera) e os Hymenoptera parasitoides Copidosoma floridanum Westwood (Encyrtidae), Euplectrus sp. (Eulophidae) emergiram de A. flava e, C. floridanum e uma espécie não identificada de taquinídeo, de $\boldsymbol{P}$. includens. Este é o primeiro relato da associação entre $\boldsymbol{S}$. frugiperda, $\boldsymbol{P}$. includens $\boldsymbol{e}$ A. monuste orceis e seus parasitoides C. floridanum e Euplectrus sp. em plantas de quiabo.

Palavras-chave: Abelmoschus esculentus, Copidosoma floridanum, Euplectrus, Hymenoptera parasitoides, Tachinidae.

The okra fruit, Abelmoschus esculentus L. (Malvaceae), is much appreciated in Brazil as a cooked vegetable in many popular recipes. The plant was brought by slaves from Africa to Brazil, where it is grown all year round in the hotter regions; okra provides vitamins $\mathrm{A}$ and $\mathrm{C}$, calcium, niacin, antioxidants, potassium and magnesium, as well as other nutrients and fiber (SILVA et al., 2007). This vegetable is produced on a large scale in the state of São Paulo, where in 2010 the crop occupied about 1,800 hectares and filled 1.4 million boxes of $16 \mathrm{~kg}$, around $60 \%$ of the

'Apta Regional Centro Leste, Agência Paulista de Tecnologia dos Agronegócios (APTA), Av. Bandeirantes, 2419, 14030-670, Ribeirão Preto, SP, Brasil. E-mail: rirlara@apta.sp.gov.br. Autor para correspondência.

"Programa de Pós-graduação em Agronomia (Entomologia Agrícola), Departamento de Fitossanidade, Faculdade de Ciências Agrárias e Veterinárias, Universidade Estadual “Júlio de Mesquita Filho” (UNESP), Jaboticabal, SP, Brasil. 
production being concentrated in Campinas and Araçatuba districts (IEA, 2011).

One of the main problems facing okra growers is the frequent infestation by arthropod pests that spoil the fruit and can result in the loss of up to $30 \%$ of production (PICANÇO et al., 2000). In Brazil, a wide variety of such pests attack the okra plant, the most damaging being the Aphis gossypii (Glover), Smynthurodes betae (Westwood), Empoasca kraemeri (Ross \& Moore) and Bemisia tabaci (Gennadius) biotype B (Hemiptera); Agrotis ipsilon (Hufnagel) and Pectinophora gossypiella (Saunders) (Lepidoptera); Eutinobothrus brasiliensis (Hambleton) and Allocolaspis brunnea (Jacoby) (Coleoptera); Frankliniella schultzei (Trybom) (Thysanoptera); Solenopsis saevissima (F. Smith) (Hymenoptera) and, Mononychellus planki (McGregor), Tetranychus urticae (Koch), T. Iudeni (Zacher) and Polyphagotarsonemus latus (Banks) (Acari) (PICANÇO et al., 2000; LEITE et al., 2005; SILVA et al., 2007).

Little is known about the insect community associated with okra plants grown in Brazil and even less about associations between the herbivores that infest these plants and their parasitoids. Therefore, this research studied the lepidopterans and their parasitoids found in an experimental plot of okra in Riberão Preto in southeast Brazil.

The research was carried out in a $5000 \mathrm{~m}^{2}$ experimental field of okra ( $21^{\circ} 12$ ' $15^{\prime \prime} \mathrm{S} / 47^{\circ} 52$ '14” W) belonging to the Agência Paulista de Tecnologia dos Agronegócios (APTA), Apta Regional Centro Leste, Ribeirão Preto, SP, Brazil. In March and April 2009, when the okra were in fructification stage, lepidopteran caterpillars and pupae were collected from the plants by hand, in the morning, and placed in plastic jars (14 $\mathrm{cm}$ of diameter, $20 \mathrm{~cm}$ of high) closed with netting, containing okra leaves.

The caterpillars and pupae were transported to the Laboratório de Sistemática e Bioecologia de Parasitóides e Predadores of the APTA were they were placed individually on Petri dishes lined with wet filter paper, containing shredded okra leaves, and kept in a climactic chamber $\left(25 \pm 1^{\circ} \mathrm{C}, 12: 12 \mathrm{~h}\right.$ light/dark photoperiod, RH $70 \pm 10 \%$ ) until the emergence of lepidopterans and/or parasitoids. The Petri dishes were inspected daily to monitor the development of the larvae and, at two-day intervals, when filter paper and okra leaves were replaced. The larvae were kept in the dishes until pupation and/or the emergence of parasitoids. The collected pupae and the obtained by rearing of larvae were transferred to individual $500 \mathrm{~mL}$ glass jar closed with voile cloth, where they remained until the emergence of the lepidopteran imagoes or their parasitoids.
The parasitoids were mounted on cards in entomological pins and labeled. Euplectrus (Hymenoptera, Eulophidae) was identified with a key provided by SCHAUFF et al. (1997) and Copidosoma floridanum (Ashmead) (Hymenoptera, Encyrtidae) with GUERRIERI \& NOYES (2005). The lepidopterans were identified by Dr. Manoel Martins Dias Filho of the Universidade Federal de São Carlos (UFSCar).

A total of 80 caterpillars were collected, representing five species of Lepidoptera: 67 Anomis flava (Fabricius) (Noctuidae) (83.8\% of total of caterpillars obtained), six Pseudoplusia includens (Walker) (Noctuidae) (7.5\%), three Ascia monuste orceis (Godart) (Pieridae) (3.8\%), three Spodoptera frugiperda (Smith) (Noctuidae) (3.8\%), and one unidentified tortricid (1.2\%) (Table 1$)$. In addition, 41 pupae of A. flava were collected. The highest abundance of A. flava was recorded in March 2009, when 40 caterpillars (59.7\%) and 39 pupae (95.1\%) were found. From larvae and pupae collected were obtained 63 lepidopterans: A. flava (53 adults/84.1\% of total of adults obtained), $\boldsymbol{S}$. frugiperda (three/4.8\%), $\boldsymbol{P}$. includens (three/4.8\%), A. monuste orseis (three/4.8\%), and an unidentified species of Tortricidae (one/1.5\%).

Out of the 67 A. flava larvae, 14 (20.9\%) were parasitized by $\boldsymbol{C}$. floridanum, five (7.5\%) by an unidentified species of tachinid (Diptera) and one (1.5\%) by Euplectrus sp., resulting in a rate of parasitism of $29.9 \%$. Among the six caterpillars of $\boldsymbol{P}$. includens, two (33.3\%) were parasitized by $\boldsymbol{C}$. floridanum and one (16.7\%) by an unidentified tachinid, giving a total of $50.0 \%$ parasitism. This rate refers to the apparent parasitism because the larvae that died during the development of the research were not dissected.

This is the first report of $\boldsymbol{A}$. flavus associated with A. esculentus (okra) in Brazil. This association has been observed in Nigeria (ESSIEN \& ODEBIYI, 1991) and in India (NETAM et al., 2007). Moreover, the associations between $\boldsymbol{S}$. frugiperda, $\boldsymbol{P}$. includens and A. monuste orceis larvae and okra plants are reported here by the first time. Spodoptera littoralis (Boisduval) was reported destroying okra crops in Ghana (OBENGOFORI \& SACKEY, 2003). The presence of $\boldsymbol{S}$. frugiperda and $\boldsymbol{P}$. includens larvae at low population densities in the okra plot might have been due to the proximity of experimental fields of corn (Zea mays L.) and soybean (Glycine $\max$ (L.) Merrill).

Additionally, this paper presents the first recorded association of $\boldsymbol{A}$. flava with $\boldsymbol{C}$. floridanum and Euplectrus sp. and of these two parasitoid wasps with an okra crop. The cosmopolitan Copidosoma 
Table 1 - Lepidopteran larvae and pupae collected in crop of Abelmoschus esculentus L. (Malvaceae) and their emerged adults in the laboratory. Ribeirão Preto, SP, March and April 2009.

\begin{tabular}{|c|c|c|c|c|c|c|c|c|c|c|}
\hline \multirow[b]{2}{*}{ Lepidoptera } & \multicolumn{2}{|c|}{ 3/09/2009 } & \multicolumn{2}{|c|}{ 3/16/2009 } & \multicolumn{2}{|c|}{ 3/23/2009 } & \multicolumn{2}{|c|}{ 4/07/2009 } & \multicolumn{2}{|c|}{$4 / 17 / 2009$} \\
\hline & $\mathrm{L} / \mathrm{P}$ & A & $\mathrm{L} / \mathrm{P}$ & A & $\mathrm{L} / \mathrm{P}$ & A & $\mathrm{L} / \mathrm{P}$ & A & $\mathrm{L} / \mathrm{P}$ & A \\
\hline Anomis flava & $19 / 9$ & 20 & $8 / 10$ & 4 & $13 / 20$ & 25 & $24 / 2$ & 3 & $3 / 0$ & 1 \\
\hline Pseudoplusia includens & $1 / 0$ & 1 & & & & & $2 / 0$ & 2 & $3 / 0$ & \\
\hline Ascia monuste orceis & $1 / 0$ & 1 & $2 / 0$ & 2 & & & & & & \\
\hline Spodoptera frugiperda & & & & & $1 / 0$ & 1 & $2 / 0$ & 2 & & \\
\hline Tortricidae & $1 / 0$ & 1 & & & & & & & & \\
\hline
\end{tabular}

$\mathrm{L} / \mathrm{P}=$ larva and pupae

$\mathrm{A}=$ adult.

includes around 190 species and those whose biology has been described scientifically act as endoparasitoids of eggs and larvae of lepidopterans (GUERRIERI \& NOYES, 2005). C. floridanum is known to attack 45 species in five lepidopteran families (NOYES, 2010), two of which are Noctuidae and Tortricidae, both collected in this study. Euplectrus, another cosmopolitan genus, includes around 130 species, some of which have been used for biological pest control. There are reports of association between Euplectrus and Anomis sp. and A. leona (Schaus) (NOYES, 2010).

Few reports have been published on parasitoids of arthropod pests of okra crops. In Brazil, LEITE et al. (2005) observed Encarsia sp. (Hymenoptera: Aphelinidae) parasitizing white fly on okra plants. In India, TELANG et al. (2004) and DHANE et al. (2007) conducted trials in which the Hymenoptera parasitoid Trichogramma chilonis (Ishii) (Trichogrammatidae), Chelonus blackburni (Cameron) and Rogas aligarhensis (Qadri) (=Aleiodes aligarhensis) (Braconidae) and Brachymeria lasus (Walker) (Chalcididae) were tested for biological control of lepidopterans Earias vittella (Fabricius).

\section{ACKNOWLEDGMENTS}

The researchers thank the Instituto Nacional de Ciência e Tecnologia dos Hymenoptera Parasitoides da Região Sudeste Brasileira (CNPq/Fapesp/Capes) for financial support.

\section{REFERENCES}

DHANE, A.S. et al. Field evaluation of C. blackburni against shoot and fruit borer $\boldsymbol{E}$. vittella infesting okra. Indian Journal of Entomology, v.69, n.1, p.54-57, 2007.

ESSIEN, R.A.; ODEBIYI, A. Biology of Anomis (=Cosmophila) flava (F.) (Lepidoptera: Noctuidae) on okra (Abelmoschus esculentus (L.) Moench) in Nigeria. Journal of African Zoology, v.105, n.1, p.17-25, 1991.

GUERRIERI, E.; NOYES, J.S. Revision of the European species of Copidosoma Ratzeburg (Hymenoptera: Encyrtidae), parasitoids of caterpillars (Lepidoptera). Systematic Entomology, v. 30, n.1, p.97-174, 2005. Available from: <http://onlinelibrary.wiley.com/doi/10.1111/j.13653113.2005.00271.x/pdf>. Accessed: Mar. 2011.

INSTITUTO DE ECONOMIA AGRÍCOLA (IEA). Área e produção dos principais produtos da agropecuária. Available from: <http://ciagri.iea.sp.gov.br/bancoiea/ subjetiva.aspx?cod_sis=1\&idioma=1>. Accessed: Mar. 2011.

LEITE, G.L.D. et al. Whitefly population dynamics in okra plantations. Pesquisa Agropecuária Brasileira, v.40, n.1, p.19-25, 2005. Available from: <http://www.scielo.br/pdf/pab/ v40n1/23237.pdf $>$. Accessed: Mar. 2011. doi: 10.1590/S0100204X2005000100003.

NETAM, P.K. et al. Insect pest succession in okra. Environment and Ecology, v.25, n.1, p.177-180, 2007.

NOYES, J.S. Universal Chalcidoidea database. World Wide Web electronic publication. Available from: <http:// www.nhm.ac.uk/chalcidoids>. Accessed: Nov. 2010.

OBENG-OFORI, D.; SACKEY, J. Field evaluation of nonsynthetic insecticides for the management of insect pests of okra Abelmoschus esculentus (L.) Moench in Ghana. Ethiopian Journal of Science, v.26, n.2, p.145-150, 2003.

PICANÇO, M. et al. Manejo integrado de pragas de hortaliças. In: ZAMBOLIM, L. Manejo integrado - doenças, pragas e plantas daninhas. Viçosa: UFV, 2000. Cap.8, p.275-324.

SCHAUFF, M.E. et al. Eulophidae. In: GIBSON, G.A.P. et al. Annotated keys to the genera of Nearctic Chalcidoidea (Hymenoptera). Ottawa: NRC Research, 1997. p.327-429.

SILVA, M.B. da et al. Quiabo (Abelmoschus esculentus L.). In: PAULA JR., J.; VENZON, M. 101 culturas: manual de tecnologias agrícolas. Belo Horizonte: EPAMIG, 2007. p.653-670.

TELANG, S.M. et al. Parasitization by different parasites of $\boldsymbol{E}$. vitella in okra. Journal of Soils and Crops, v.14, n.2, p.335339, 2004. 